\title{
RELIGIOUS PLURALISM AND CHRISTIAN RESPONSES
}

\author{
Enggar Objantoro \\ Simpson Theological College \\ Jl. Agung No. 66, Krajan, Kel. Susukan, Kec. Ungaran Timur, Kab. Semarang, Jawa Tengah \\ Email: enggarobj@sttsimpson.ac.id
}

\begin{abstract}
Abstrak: Enggar Objantoro, Pluralisme Agama dan Tanggapan Kristen. Pluralisme agama merupakan paham yang mem-percayai bahwa semua agama di dunia ini sama. Kaum pluralis percaya bahwa kebenaran-kebenaran yang ada dalam semua agama mempunyai nilai yang sama, tidak ada agama yang lebih tinggi dari agama yang lain. Pluralisme agama menjadi tantangan yang sangat serius bagi kekris-tenan, sebab paham itu menolak kebenaran Alkitab yang menyatakan bahwa Tuhan Yesus adalah satu-satunya Juruselamat manusia. Kekristenan harus menjawab kritikan-kritikan kaum pluralis terhadap kebenarankebenaran Alkitab, dengan memberikan argumentasi yang jelas dan tegas. Teolog-teolog Injili percaya bahwa kebenaran-kebenaran Alkitab merupakan sesuatu yang khas/unik dalam kekristenan, yang tidak sama dengan kebenaran-kebenaran dalam agama-agama lain.
\end{abstract}

Kata Kunci: Pluralisme, Kristen, Agama

Abstract: Enggar Objantoro, Religious Pluralism and Christian Responses. Religious pluralism believes that all religions are equal. Pluralists believe that the truths in religions have the same value, there is no religions higher than other. Religious pluralism is serious challenge for Christianity, because they reject the biblical truth that Jesus is only the savior for human being in the world. Christianity has to response to the pluralist critiques over the biblical truths, based on the Word of God. Evangelical theologians believe that the biblical truth is unique, and is just in Christianity. It is different with the truths of other religions.

Keywords: Pluralism, Christian, Religion

\section{INTRODUCTION}

Today, the world moves toward technology developments in which it has never happened in the previous centuries. The population of the world grows up year after year, so there are billion people in the world now. In technology, there are so many new discoveries in medical and information technology that they help people easier to live in the world. People are able connected to other people quickly, so they have interaction each other. This era is also signed by the revivalism of religions. Many people have beliefs in their religions, and they share their beliefs to other people.

The situation above urge for emerging the religious pluralism. On the one hand, the religious pluralism is not able avoided because the society is plural. The society consist of many people who have many backgrounds, both ethnic, language, culture and religion. On the other hand, it is recognized that religious pluralism is one of the serious challenges for Christian theology today, because it influences many Christians in the world. Pinnock (1990, p. 359) said, "Religious pluralism is widely recognized to be one of the primary challenges to theology in our time". It formulates some concepts that reject some essential Christian beliefs. Hence, in order to answer the religious pluralism arguments, all Christians have to really understand the main concepts of religious pluralism.

Therefore, this issue is important to discuss based on the biblical truths. Moreover, books or article that discuss about it is very limited. For the reason, the writer is interested to examine the issue. This paper emphasizes the understanding of what the religious pluralism means, what is the critiques of religious pluralism to Christian theology, how should Christian theology response to religious pluralism attack. 


\section{METHOD}

In this article, the writer uses qualitative research based on literature study, which focus on the prominent pluralists in the religious study, like: Paul F. Knitter, John Hicks, etc., because they have published their insights which influence many people. The writer responses their insights according to the Bible truths.

\section{RESULTS AND DISCUSSION}

\section{The Understanding of Religious Pluralism}

Some scholars or theologians have defined the meaning of religious pluralism. Panikkar (1979) defines pluralism as existential acceptance of the other as the other i.e., without being able to understand or to co-opt him. Pluralism is humble, only knows that I or we may not possess the whole truth and does not pass judgment as to whether the other may also be right or, as it may turn out, wrong. For Kenneth Samples (2003), "Religious pluralism is the view that all religions, certainly all major religions, offer equally valid paths to God, or to ultimate reality.” Diana L. Eck (2007, p. 743) said, “... Religious pluralism is a critical theological issue for people of faith, raising fundamental questions about one's own faith in relation to the religious other." In Pluralism, there is no superior religion. All religions are equal. Religious pluralism is influenced by postmodern view, which believe (2013) "there is no absolute truth and truth is relative". For postmodernist, the religion truths is relative. It means that a religion cannot claim that his truth is true, while other religion is untrue. On the word, John Hick (2005, p. 11) said, "...no one religion has a monopoly of the truth or of the life that leads to salvation." According to pluralists, the religious pluralism view is important to overcome the conflict among the people who have different religions, even the conflict among the people in the same religion/denomination. They believe that if people who have religions understand about the equality in the truths in religions, the conflict can be avoided.
Whereas, McGrath (1996, p. 575) said, pluralism is "An approach to the relation of Christianity and other faiths which regards the world's religions as equally valid manifestations or representations of the same fundamental reality." This definition stress the similarities in all religions, they have the same fundamental reality. Based on the similarities, they claim that all religions are true. Lesslie Newbigin (1989, p. 14) defines religious pluralism as "...the belief that the differences between perception of the one truth; that to speak of religious beliefs as true or false is inadmissible. Religious belief is a private matter." Newbigin stresses, for pluralists, all religions have truths in which other people cannot judge it. But, Peter C. Phan (2003, p.501) states that "Religious pluralism...is not just a matter of fact but also a matter of principle." Christianity has to aware toward religious pluralism.

The concept of religious pluralism has big impact to fundamental Christian beliefs. One of them is about the concept of salvation. Okholm and Phillips (1995, p. 17) notices that religious pluralism maintains that the major world religions provide independent salvific access to the divine Reality. Pluralists believe that there is salvation in all religions. Religious Pluralism rejects at least two fundamental Christian beliefs, these are "(1) Jesus Christ is the only Savior. (2) No one can be saved unless he or she knows the information about Jesus' person and work contained in the Gospel and unless he or she exercises explicit faith in Jesus Christ." (Nash, 1994, p. 25). Religious pluralism emphasizes the similarities among religions, and based on that, it concludes that all religions are equal.

\section{The Arguments of Religious Pluralism}

There are some arguments that are used by pluralists to defend their concepts about religious pluralism.

\section{God as Center of All Religions}

John Hick has significant role in religious pluralism. Nash (1994, p. 29) recognizes him as “... 
generally acknowledged to be the best-known and most influential proponent of pluralism today." "Copernican Revolution' is very important to understand the Hick's basic concept of religious pluralism. Hick proposed some fundamental concepts about religion in order that every religion has respect to each other because, basically, according to Pluralist, that all religions are equal. According to Ariarajah (1991, p. 174), "Hick pointed out that in a pluralistic world it was not appropriate for one religion to set itself as the only unique and universal revelation." Through his 'revolution,' he criticizes the exclusivity of Christianity because Christianity understands God in Christ Jesus. Hick (quoted by Ariarajah, 1991, p. 174) said, "We have to realize that the universe of faiths centres upon God, and not upon Christianity or upon any other religion. He is the sun, the originative source of light and life, whom all the religions reflect in their different ways." Hick rejects the Christocentric theology because it cannot be applied for other religions. He proposed 'theocentric' theology so that other religions can be accommodated in his theology. For him, theology should be "...a 'theocentric' theology of religions, where God alone and not Christ or Christian church is given pride of place at the center of things." (Fredericks, 1999, p. 38). All religions can accept 'theocentric' theology because all religions have God who is worshipped.

Hick's concept is supported by other pluralist, such as Stanley Samartha. He has an idea that Christian should relativize the concept of God because in the incarnation God relativizes himself (Knitter, 1984, p. 158). He confirms that a theocentric approach, which he holds, will be more faithful to the original message of Jesus himself (Knitter, 1984, p. 158). By using a theocentric model for understanding and encountering other religion, Knitter (1984, p. 159) said that "Christians will still be able to hold to their personal commitment to Christ and to their belief in his universal meaning." Samartha disagree with the Christocentric model because it has infected Christian doctrine and so absolutizes Jesus that it turns him into 'a kind of cult figure over against other religious figures' (Knitter, 1984, p. 158).

Likewise Paul Knitter, he proposed the concept of 'unitive pluralism.' This concept is built on the assumption that the 'many' affirmed in the pluralistic understanding 'cannot exist in splendid isolation' (Ariarajah, 1991, p. 177). The reason for that is because there is a growing relationship and unity between religions, which should be seen as a movement, not towards absolute or monistic oneness, but towards a new kind of unity (Ariarajah, 1991, p. 177). Religious pluralism teaches that all religions have the same access to God because God is the center of all religions. There is no superior religion. All religions are equal. Pluralism insists all religions to unite, to relate each other in mutual dependence because there are no essential differences among them.

\section{Morality in the Major World Religions}

Pluralists notice that all religions have the same concerned on the moral or the human goodness that reflects a right relationship to God. Hick (quoted by Okholm \& Phillips, 1995, p. 38) states that "The basic ideal of love and concern for others..., taught by all the great religious traditions." Hick finds out that all religions have the same concept that every believer has to do the right thing to other people. If in Christianity, there is "Golden Rule", as Jesus said, "As you wish that men would do to you, do so to them" (Luke 6:31), there is concept like that in other religions as well.

Confusius..., 'Do not do to others what you would not like yourself' (Analects, XII:2). Taoism ...the good man 'will regard [others'] gains as if they were his own, and their losses in the same way" (Thai Shan,3). Zorastrianism..., 'That nature only is good when it shall not do to another, whatever is not good for its own self' (Dadistan-i-dinik, 94:5) In the Hindu..., 'One should never do that to another which one regards as injurious to one's own self. This, in brief, is the rule of Dharma' (Anushana parva, 113:7)...The Buddhist scripture...'As a mother cares for her son, all her days, so towards all living things a man's mind should be all-embracing' (Sutta Nipata, 149). The Jewish Talmud 
...' what is hateful to yourself do not do to your fellow man. That is the whole of the Torah' (Babylonian Talmud, Shabbath 31a). And in Islam..., 'No main is a true believer unless he desires for his brother that which he desires for himself' (Ibn Madja, Intro. 9). (Okholm \& Phillips, 1995, p. 39-40).

It is obvious that all religions concern with the moral values in this life. In the reality, not all followers of religions do that, so there is global picture that "the virtues and vices seem to be spread more or less evenly among human beings, regardless of whether they are Christians or Jews, Muslims, Hindus or Buddhists." (Okholm \& Phillips, 1995, p. 41). There are good and evil in all religions. Therefore, Hick (quoted by Okholm \& Phillips, 1995, p. 42) concludes that "...one cannot establish the unique moral superiority of any one of the great world religions."

\section{The Ineffability of Religious Experience}

For Pluralist, religious experience is considered as an important thing for all human being. John Hick (quoted by Okholm \& Phillips, 1995, p. 43) said that “...religious experience...is important. God is always and everywhere present to us-above, beneath, around, and within us. And when a human being is exceptionally open to the divine presence, he or she has a vivid awareness of God, which is then called revelation." For Hick (quoted by Netland, 1991, p. 203), "religious experience is basic to religious epistemology." Religious pluralism stresses that all people in every religion have the same experience with God. As his experience in the relationship with other people who have different religions, John Hick (quoted by Netland, 1991, p. 38) noticed that

...from a religious point of view basically the same thing is going on in all of them, namely, human beings coming together within the framework of an ancient and highly developed tradition to open their hearts and minds to God, whom they believe makes a total claim on their lives and demands of them.

\section{The Phenomenon of Salvation}

Salvation is not considered as the special thing for pluralists because they argue that the meaning of salvation depends on how human being defines it. Hick (quoted by Netland, 1991, p. 43) define salvation as an actual human change, a gradual transformation from natural self-centeredness to a radically new orientation centered in God and manifestted in the "fruit of the Spirit". From that position, they considered that all religions lead to salvation (Fredericks, 1999, p. 7). Pluralists believe that salvation is not just in Christian.

Furthermore, Hick (quoted by Okholm \& Phillips, 1995, p. 43-44) points out that the idea about salvation exists in all religions although it is not expressed in the same terms.

Salvation is primarily a Christian term. Redemption is common to Christians and Jews. Muslims think in terms of a total submission to God, who is the giver of life and who is ever gracious and merciful to humankind. The Eastern religions do not always experience the ultimate reality we call God as a personal being and do not think primarily in terms of guilt and forgiveness. Rather, this transformation is experienced as liberation or enlightenment, that is, the dispelling of the spiritual blindness of avi$d y a$ and the discovery of ultimate oneness with Brahman, the eternally real. Another characteristic Eastern term is awakening, that is, awakening to the true nature of reality when experienced from a universe rather than an egocentered point of view; this transformed consciousness, whose expression is comparison for all of life, is nirvana.

Hick considers that all terms above are the same meaning because all of them express "...the fundamental human transformation from self-centeredness to a recentering in the ultimately Real...." (Okholm \& Phillips, 1995, p. 44). All religions refer to the Ultimate. Also, according to Pluralism, "...the question of limited or universal salvation/liberation applies equally to the people of all religions and even to those without one." (Okholm \& Phillips, 1995, p. 45). In other words, pluralism believes that people in all religions have the same chance to be saved or 
not. They believe that there are people among them that will be saved and others not.

\section{Christian Responses To Religious Pluralism}

Pluralism becomes a challenge for Christian theology because they deny fundamental Christian insights. It is a task a Christian to answer every ideas of religious pluralism in order to maintain biblical teachings.

\section{The Doctrine of God}

"Copernican Revolution" that is proposed by John Hick arise a big question about God, although all religions have God who they worship. However, do all religions refer to the same God? There are different concepts about God among religions, as Nash (1994, p. 35) said, “...many religious system express belief in a non personal Supreme Principle; others neither affirm nor deny the existence of a personal God." Christianity, Judaism, and Islam understand God as personal God, but Hinduism, Buddhist and other have different perspective about God.

Hick's revolution just emphasizes God as center of all religion. However, he does not have other explanation about God. From Hick's (quoted by Nash, 1994, p. 36) point of view, he understands God just as something that exceeds all human thought. It means that, for Hick, God is unknowable. This position is very contrast with Christian belief because God in Christianity is God who can be known in Christ Jesus. There are no religions that have concept about God like in the Christianity. This point is one of strengths of Christianity compared with other religions because Christians worship God who is known. Therefore, Hick's (quoted by Nash, 1994, p. 38) concept about God cannot be defended. Hence, it just causes a philosophical and theological disaster.

Even though, pluralists criticize the exclusivity of Christianity, especially about the concept of God. However, it does not wonder. Other religions have tendency to be exclusive as well, even pluralist.
Kenneth Richard Samples (2003) comments pluralism's critics upon Christianity by using Alvin Plantinga's rhetorical question: "Doesn't the pluralist believe exclusively that all religions are equally good paths to God? Christianity's exclusivism arises not from the narrow mindedness of individual Christians but from the exclusive claims of Jesus Christ (Mt.11:27; Jn 14:1-6), attested by those who were eyewitnesses to his life, death, and resurrection (Jn 3:36; Acts 4:12; 1 Tim 2:5; 1 Jn 5:11-12)." Christian understands the concept of God from the Bible.

\section{Morality}

Moral aspect that religious pluralism considers as a standard of equality of religions is not sufficient because, as Pinnock (Quoted by Okholm \& Phillips, 1995, p. 44) said, "Every religion produces saints, so it doesn't really matter what one believes about God." Many people can have a good moral, even atheists, but it does not mean that they really believe in God. Non-Christians can have better moral than Christian. The belief in God does not just superficial in human life, but there must have a radical transformation in the deep inside of the human heart. The main problem does not just about moral, but as the Bible teach that "...all human persons, regardless of religious affiliation, are sinners in need of divine grace (Isa. 64:6; Jer. 17:9-10; Rom. 3:23; 6:23; 1 John 1:9-10)." (Okholm \& Phillips, 1995, p. 78). This is one of the differences between Christian and non-Christian because there is no concept about $\sin$ in the most of non-Christian religions. Reversely, in Christianity, the concept about sin is very important for believers to be considered because moral value becomes meaningless if human being is still sin before God.

At this point, pluralism just emphasizes moral aspects as human attitudes. Pluralism does not consider the moral aspect in deep sense. They just consider it in superficial level in which all religions concern with moral aspect, but they do not think that there is the essential thing rather than moral aspect, namely sin. Christian believes that there is no way 
for human being to accomplish the problem of $\sin$ in this life, except through Christ Jesus. Pluralism expects that their morality can become a way to accomplish it, but the Bible said that our goodness has already polluted by sin, so it can become solution of sin. Christianity has the strong basis to explain about the role of morality in the human life.

\section{Religious Experience}

Pluralism recognizes that there is a religious experience in all religions. They believe that religious experience is a revelation from God because they experience the invisible, higher and supernatural power. They believe that the experience can become a strong basis to say that all religions are equal. There is no a certain definition about religious experience in pluralism. They just think that religious is very important for every human being because it is time to experience divine reality. They believe that religious experience is a sign of God's truth.

For Christian perspective, religious experience does not mean conversion because religious experience has broad meaning. Hence, one can say that conversion is part of religious experience. One can have some religious experiences, but, may be, that is not an experience of conversion in this life. For Christian, religious experience has not yet become the conversion experience if they do not know Christ Jesus as the Lord and Savior. Pluralism just emphasizes that they have religious experience too, the same with other people in different religion. It must be recognized that religious experience is very important. All religions recognize it. However, in Christianity, religious experience itself is not enough. One should have a definite experience to encounter with Christ personally.

Therefore, in Christianity, there is a unique religious experience that is not had by other religions. The most important of religious experience is the experience when man meet God in Christ personally because it is a moment in which God transforms his life into the new one (II Cor. 5:17). This experience becomes a starting point for him to get other religious experience with God in this life. Without conversion experience, religious experience becomes meaningless. And it must be examined: does the religious experience come from God? Many religious experiences, actually, does not come from God. It can be that it comes from demon or others. Many people recognize some religious experience from God, but, actually, that is not from God. For Christian, religious experience becomes meaningful in Christ work at the Cross. The essential thing of religious experience is that God come to human being to save them from the bondage of sin. Christian is the only religion that proclaims that message for this world.

\section{Salvation in Christ}

Pluralism has no a specific concept about salvation. They understand salvation in broad meaning. Hence, there is question about that; is the salvation the same with the concept of liberation? Is the salvation the same with the change of orientation from self-centeredness to divine-centeredness? The questions are still in general level of salvation.

Christianity, strongly, will say no to answer the question above. Even though, in the one hand, Christianity recognizes that one of aspect salvation is liberation because salvation make human being free from the bondage of sin. Also, salvation leads human being to focus on God in this life. However, salvation does not just talk about it. Salvation must be related to the Christ's work at the cross because salvation is God's work for His creation. This point differs Christianity from other religions, as Hans Kung (Quoted by Aldwinckle, 1982, pp. 50-51) said, "...that what distinguish Christianity from other religions are not its symbolic, theological, or metaphysical concepts but the simple fact of Jesus." The concept of salvation will be meaningless or useless if there is no relation with Jesus Christ. The uniqueness of Christianity is on the person of Jesus Christ as Savior "...because he saves men and women both by present power and future hope. In the actual business of living and dying, he rescues men 
and women from the threats of meaninglessness, sinfulness, alienation, and death." (Aldwinckle, 1982, pp. 50-51). Christ Jesus gives hope for human being not just in the present life, but also to the future.

Jesus Christ can do that because of two natures on Him so He can incarnate in His creation. The concept of the two natures of Jesus Christ and His Incarnation are very important in Christianity as Nash (1994, p. 85) said, "The Incarnation is an essential Christian belief. If this doctrine is false, the Christian faith is false. Correct thinking about Jesus Christ diminishes neither his full and complete humanity nor his full and complete deity. Jesus Christ is God.... But he is also human. Any wavering on either claim results in a defective Christology and a heretical faith." Because this doctrine is very essential in Christian belief, many heretics try to attack this core doctrine, one of them is pluralism. Hick (Quoted by Nash, 1994, p. 85) attacks this doctrine by saying that "...claims that Jesus is both God and man are self-contradictory and meaningless as statements that a drawn figure is a square circle." Pluralism is very confused with the two natures of Christ because they always emphasize God as center. Hick (Quoted by Nash, 1994, p. 85) criticizes this doctrine; he said

The Christian God has attributes such as omnipotence, omniscience, incorporeality, and sinlessness. God also exists necessarily, which means, among other things, that there can be neither beginning nor end to his existence. Moreover, these properties belong to God essentially of necessarily, which is to say that if God were to lose any of these essential properties, he would cease to be God. A being cannot be God if he lacks omnipotence, omniscience, and the like.

Hick see that Jesus cannot become a man because if His deity will be lacked. Nash (1994, p. 89) answers Hick's attack by using orthodox Christology formulation:

(1) Jesus Christ is fully God - that is, he possesses all the essential properties of God, (2) Jesus Christ is also fully human - that is, he possesses all the essential properties of a human being, none of which turn out to be limiting properties, and (3) Jesus Christ was not merely human that is, he did not possess any of the limiting properties that are in fact complements of the divine attributes.

Therefore, Nash (1994, p. 90) states that "Christians can safely conclude, that even though they cannot understand everything about the Incarnation and the relationship between Christ's human and divine nature, the doctrine are logically coherent."

For Christian, Jesus Christ is unique because $\mathrm{He}$ is the only Savior for human being as stated in Acts 4:12 - "And in none other is there salvation: for neither is there any other name under heaven, that is given among men, wherein we must be saved." Pluralism disagrees with that interpretation. Robinson (Quoted by Aldwinckle, 1982, p. 61) states that "...this has been a misleading and unfortunately exclusive interpretation of the text...the context is not that of comparative religion but of faith healing." Robinson stresses that the context of the passage does not talk about that. According to Robinson (Quoted by Aldwinckle, 1982, p. 61), that “...is not an exclusive claim for the saving power of Jesus over all other possible saviors. It is rather a question of the source of his healing power and whether the apostles are working miracles of healing through some innate divine power of their own." Robinson considers the statement does not refer to the discussion about salvation, but about the source of power healing of the apostle. Aldwinckle disagree with pluralism's interpretation. For him, "The heart of the matter is that Christian faith has claimed that in Jesus we meet not only a prophet, a proxy, an ambassador, a messenger from God, but God personally and savingly active in a unique way and here again the cross is central. Unique here means that no other person in human history can be substituted for Jesus or can accomplish or has accomplished what he did." (Aldwinckle, 1982, p. 61). This statement gives a clear description that Jesus is the only Savior for human being.

For Christian, the claim that Jesus is the only Savior is true because this claim based on biblical truth. And also if it is related to the reality 
how Jesus can transform many people, the truth becomes so clear that Jesus is the only Savior that God determines for human being. The truth of Christ is confirmed by the scriptural truth and the reality, so the claim of the uniqueness of Christ in Christianity can be defended. It is obvious that pluralism have some presuppositions that are established subjecttively. They have constructed the concept based on their assumption and they deny all the truth from other. Pluralism just accepts presuppositions that are agree with their ideas. Therefore the doctrine of Christ from Christian perspective is not considered. For Hick and other pluralist, Jesus cannot be more than an inspiring example, whatever the evidence is! (Okholm \& Phillips, 1995, p. 63). From that point, pluralism cannot be accepted as truth because they keep their opinion without considers other opinion that against with their opinion. They will consider other opinion that agree with their opinion.

\section{CONCLUSION}

Most of pluralism arguments regarding some Christianity beliefs cannot be defended. They do not have strong foundation both philosophically and theologically. They just emphasize on the commonalities of world religions, and then they generalize all religions supposed to be like that. Therefore, on the one hand, Christianity should reject the pluralism concepts that can be justified in the light of the biblical truths. Christianity should maintain that Christian beliefs are unique that are different from other world religions. Christians should stand firm in the biblical teachings, even though, for that

\section{BIBLIOGRAPHY}

Aldwinckle, Russell F. 1982. Jesus - A Savior or the Savior? Macon: Mercer University Press.

Ariarajah, Wesley. 1991. Hindus and Christians: A Century of Protestant Ecumenical Thought. Grand Rapids, MI: William B. Eerdmans.

Carino, Feliciano V. and Marina True (Editor). 1999. Faith and Life in Contemporary Asian realities. Darwin, Australia, 1999. matter, Christian have to face many critics from other people. However, it does not mean that Christian does not want to be corrected by other people, but Christians should prioritize the God's truth based on the Bible.

On the other hand, Christianity should realize the reality in this world. It is recognized that pluralism is unavoidable because there are so many distinctions among the society. Christianity should live with other people who have many differences. The researcher agrees with the statement that religious pluralism is something we Asians have to live with (Carino and True, 1999, p. 111). Christian should respect with other people because God have placed Christian among other people in order to become blessing for them. However, it does not mean that Christians should relativize the biblical teachings in order to be accepted by other people. It is incorrect that "In accepting pluralism, we are stating that none of us has the final truth. It is through interaction which can be full of tension that we can accept the differences and live with them for the present moment." (Hao, 1996, p. 172). The relationship with other people who have different religions should not change everything in Christianity. Christians should have integrity when encounter with other people. Christian should always realize that pluralism can "...foster the interchange and promotes greater understanding." (Hao, 1996, p. 172). However, at the same time, pluralism can also confuse Christianity itself. Christians should be aware with that.

Eck, Diana L. 2007. "Prospects for Pluralisme: Voice and Vision in the Study of Religion", Journal of the American Academy of Religion, Volume 75 (4): 743-776, https://doi. org/10.1093/jaarel/lfm061.

Fredericks, James L. 1999. Faith among Faiths: Christian Theology and Non-Christian Religions. New York: Paulist Press. 
Hao, Yap Kim. 1996. “Ground of Pluralism”. Doing Theology with Asian Sources.

Hick, John. 2005. "Religious Pluralism and Islam", unpublished article. Tehran: Institute for Islamic Culture and Thought.

Knitter, Paul F. 1984. No Other Name? Maryknoll, New York: Orbis Books.

McGrath, Alister E. 1996. Christian Theology: An Introduction. Oxford, UK: Blackwell Publishers.

Nash, Ronald H. 1994. Is Jesus the Only Savior? Grand Rapids, MI: Zondervan Pub. House.

Netland, Harold A. 1991. Dissonant Voices. Leicester, England: Apolos.

Newbigin, Lesslie. 1989. The Gospel in a Pluralist Society. Grand Rapids, MI: William B. Eerdmans.
Okholm, Dennis L. \& Timothy R. Phillips (Ed.). 1995. More than One Way? Grand Rapids, MI: Zondervan Pub.

Panikkar, Raimundo. 1979. "The Myth of Pluralism: The Tower of Babel - A Meditation on NonViolence", CrossCurrents 29 (2): 197-230.

Phan, P.C. 2003. "Multiple Religious Belonging: Oportunities and Challenges for Theology and Church". Theological Studies, 64: 495519.

Samples, Kenneth Richard. 2003. "Responding to Religious Pluralism"; Internet. Accessed in http://www.augustinefellowship.org/ on December 11, 2003.

"What is postmodernism? What are the Characteristics of Postmodern Literature?" http://www. literary-articles.com/2013/08/what-is-postmodernism-what-are.html. Accesed 2018, Januari. 